\title{
Improving Students' Writing Competency Through The Idea-Details Strategy In Class XI IPA-2 Of SMA Negeri 1 Sukasada In The Academic Year 2016/2017
}

\author{
I Putu Ngurah Wirabawa Jelantik \\ Jurusan Pendidikan Bahasa Inggris \\ Universitas Pendidikan Ganesha \\ Singaraja, Indonesia \\ e-mail: ngurahwr65@gmail.com
}

\begin{abstract}
This study was aimed to improve the students' writing competency in XI IPA-2 at SMA Negeri 1 Sukasada through the implementation of the Idea-Details strategy. The subjects of this study was class XI IPA 2. This study was conducted in form of Classroom Action Research. The data were collected through some instruments, namely writing competency test, questionnaire, and observation checklist. The result showed that the implementation of the Idea-Details strategy was success to improve the students' writing competency in narrative and report text. The percentage of students who achieved score higher than or equal to 75 increased from $20 \%$ in preliminary observation to $85 \%$ in cycle 2 . The cycle was stopped in cycle 2 since the percentage of the students who achieved the passing score were more than $75 \%$ regarded to performance indicator.
\end{abstract}

Keywords: The Idea-Details Strategy, Writing Competency.

\section{INTRODUCTION}

In English subject, the students are required to learn four language skills namely: reading, speaking, listening and writing and the students are expected to be able to use the language communicatively. Writing skill is one of the four language skills that are taught in school. Writing is a difficult skill to be mastered (Richards and Renandya, 2002). This is because writing has relation to mind activity. According to Tucker (2015), through writing the students can express their ideas and state it onto papers. Writing also can be a medium for expression and communication. It can be a tool to reveal and relate students' own thoughts and feelings. Writing helps students express their ideas clearly and proficiently.

Regardless of its importance, writing becomes a complex skill to be taught. Writing skill becomes a complex skill beside reading, speaking and listening since it involves thinking, feeling, and reading as well as writing (Green, 1990). Writing seems to be a difficult skill to master. The problems in writing usually lies on the use of grammar (Tom, 2013). The sub-component like vocabulary, language structure and organization ideas may make writing difficult for students (Langan, 2001). In class XI IPA of Senior High School in SMA Negeri 1 Sukasada, writing competency has its own standards competencies which must be attained by the students. The Standard competency involves expressing meaning in short functional text and simple paragraph in the form of Narrative, Report, Analytical and Exposition. The standard competency is formulated into basic competency which is called "Expressing the meaning of written text in the form of: narrative, report, analytical and exposition accurately and fluently by using language variety.

From the standard competency and basic competency, there are some indicators that specifically indicate the 
competencies required. In order to get information about students' competency in school, there were some activities conducted. First, conducting an informal interview with the English teacher. Teacher was given some questions related to students' English competencies. The first question was about the students' problem in English. Teacher answered that the students faced problem in all skills (writing, reading, speaking, and listening), but the most prominent problem is in writing. She said this problem occurred because the students have little practice in writing and the students felt difficult to express their ideas in the form of writing. The teacher believed that the class which had problem in writing was XI-IPA 2.

This information led the researcher to diagnose the students' competency in writing especially in two texts, namely narrative and report. A preliminary observation was conducted to diagnose the students' writing competency in narrative and report text. It was conducted by giving a writing assignment in which the students were instructed to write narrative and report paragraph with the specific topics given. At first, students were asked to write a simple writing in the form of narrative and report paragraph. After wards their writing were scored based on the rubric assessment. The passing score in writing in SMA Negeri 1 Sukasada is 75 .

The passing score in writing at that school is 75 and the students that had problem in writing were equal to $80 \%$. It means students which had lower score than 75 were greater than the students that had higher score than 75. From the table above it can be seen that some students still had problems. There were 16 students $(80 \%)$ achieved score under the standard score 75.

In order to know more about the problems that students faced in writing, the researcher conducted an informal interview with the students. The researcher asked them about the things that made them difficult in writing. Based on the interview, most of students answered that they did not like writing because (1) they felt difficult to state or express their ideas into papers, (2) they had low mastering in sentence pattern or organize their writing in a good paragraph, (3) they had lack knowledge about grammar and vocabulary, and (4) they also felt confuse when they used the appropriate tenses. These reasons made them reluctant to participate in writing class. As the result their writing were less than the standard expected.

Reflecting on the above problems, the strategy that would be used by researcher was The Idea-Detail Strategy. The Idea-Details Strategy is one of the writing strategies that had been introduced by Steve Peha, where in this strategy students arrange the idea in their writing and gives details for each idea.

The Idea-Details strategy is one of the simple ways to teach writing for students. According to Peha (2003) the Idea-Details strategy can help students to state their ideas and also help them to organize their writing in a good paragraph. The IdeaDetails strategy also can stimulate students to write by filling the details for each main idea that the students make.

Through the implementation of the Idea-Details strategy, the students were expected to improve their writing competency. From the previous study that had been conducted by Natalia in 2011, this strategy could improve students' writing competency and the students also gave positive response toward this strategy.

Based on the rationale above, the problem can be formulated as follows:

"How could the implementation of the Idea-Details strategy improve students' writing competency in class XI-IPA 2 in SMA Negeri 1 Sukasada in the academic year 2016/2017?"

The study that the researcher would conduct focused on teaching writing of narrative and report text at class XI-IPA 2 students of SMA Negeri 1 Sukasada. The subjects that had been used in this research were limited to class XI-IPA 2. The variables that were to be investigated in seeking the improvement of students' writing skill are content, organization, vocabulary, grammar, and mechanic.

Considering the problems above, the objective of this research was to find out the students' writing skill in narrative and report text in the class XI-IPA 2 of SMA Negeri 1 
Sukasada could be improved through the implementation of The Idea-Details Strategy.

\section{THEORETICAL REVIEW Writing}

Nunan (2003: 88) defines that writing is the process of thinking to invent ideas, thinking about how to express ideas into good writing, and thinking about how to express them and organizing them into a sentence and paragraph clearly. It indicates that writing involves physical and mental act. It is called a physical act because writing is an act of committing ideas into somemedium. In addition, Rubeinstein (2013) defines writing as a process of stating ideas into printed form in order to convey some information to the readers.

Furthermore, Perrin in Palmer et al. (1994: 5) states that writing is a kind of thinking activity through written words. It means that a good writing needs a careful thinking. Those thinking can be represented in the form of generating the idea, choosing the suitable words or appropriate vocabulary, and arranging those ideas into a good sequence. This is also in line with Palmer et al. (1994) who mentions that writing requires complex thinking which is involved problem solving and decision making.

Writing skill can be difficult to master. It is because there are some components that have to be learn namely: word choices, grammar, syntax, mechanics and organization Gebhard (1996: 221). Furthermore, Brown (2001: 335) states that writing requires specialized skill like revising procedures.

\section{The Idea-Details Strategy}

According to Peha (2003), there are some steps followed in applying the strategy:

1) The first, the students are asked to think about an idea about what they want to write. The idea is in the form of sentences in which it becomes the topic sentence of the paragraph. By writing the idea, the students will start activate their prior knowledge. After the students find he idea, they should write the idea in the idea chart.
2) The second step is the students start writing the details of the idea. Students should take a note as many details as they need. The details can be written in the form of words or sentences.

3) after the students have finished writing the details, the students start to organize the details into paragraph. Students can choose the details in the details chart and organize the details with the idea in a good paragraph.

4) in the last step, the teacher monitors the students' works along the process and then the students finished their writing, the teacher teaches the students to revise their writing.

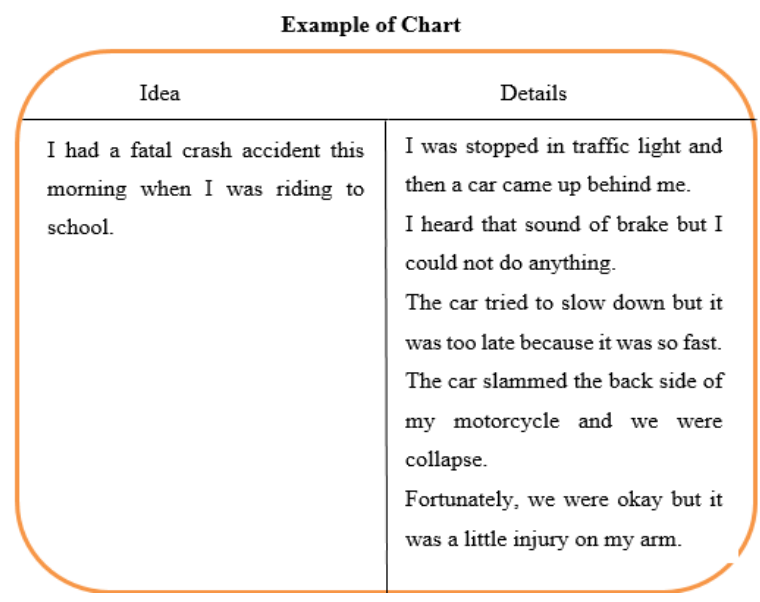

Figure 1. The example chart

\section{RESEARCH METHOD}

The design of this study was in the form of Classroom-Action Research (CAR). According to Mills (2003:5), action research is defined as any systematic investigation conducted by teacher researchers, administrators, counselors, or others with a vested interest in the teaching and learning process or environment for the purpose of gathering information about how their particular schools operate, how they teach, and how their students learn.

Koshy (2005) states that action research is a specific method conducting research by professionals and practitioners with the purpose of improving educational practice. It supports practitioners to find ways in which they can provide good quality education by transforming the quality of teaching related activities, thereby enhancing students' learning. 
Moreover, action research is an approach of collecting data and interpreting data that involves a clear repeated cycle of procedures. By doing an action research in the classroom, the researcher would learn how to conduct an effective teaching and learning process, while the students learn how to become an effective learner. Furthermore, this research conducted in order to know the implementation of the Idea-Details strategy could improve the students' writing competency.

The action research process involved in conducting this research was cyclic. Kemmis and Taggart (1998) in Natalia (2013) stated that an action research is cyclic process which involves planning. Action, observation, and reflection. The action research cycle can be figured as follow:

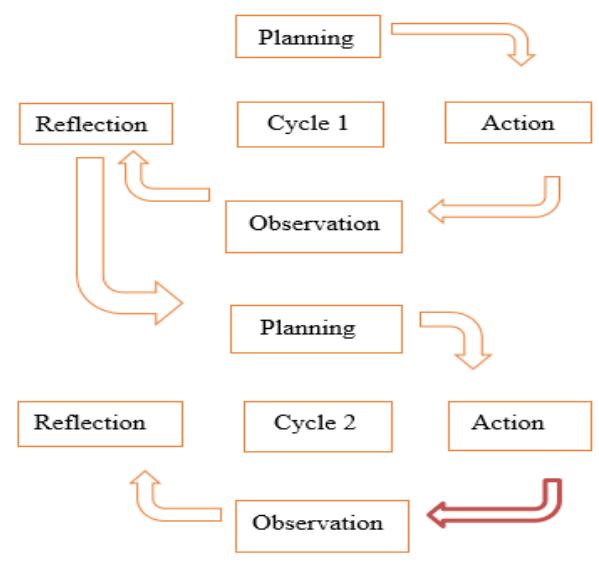

Figure 2. Research Design

The cycle process will stop until the students reach the standard score or above standard score. The phases can be described as follows:

a. Planning

Planning refers to determining sequence steps of the action and instrument used for collecting data. In planning stage, the purpose was to prepare everything which will be needed along the collecting process for each meeting in the cycle.

b. Action

Action refers to what will be done in the classroom and how the class is managed based on teaching scenario. It involved implementation of the teaching- learning process using The Idea-Details Strategy.

c. Observation

Observation refers to the process of observing the classroom situation and students' behaviors during teaching and learning process. This stage is conducted to find out the result of the action. The purpose is to find out the students' problem, responses and the students' need for improvement during the action given. There are some activities conducted in observation, such as observing the situation of the classroom during the action conducted in observation and the students' behavior during the teaching process.

Next, the evaluation is done to evaluate the students' writing competency. The evaluation will finish after the action by asking the students to write narrative and report paragraph, in which they are asked to write about the specific topic given. It was done for the purpose of finding out the students' writing competency after being treated by using The Idea-Detail Strategy.

d. Reflection

Reflection is done as the way to know the strengths and weaknesses of the action given. Reflection is done to look up and understand the process, identified the weaknesses of the action based on the result of the observation and draw conclusion. The result and evaluation of the observation is analyzed to find out the improvement in students' competency after action phase.

\section{DATA COLLECTION}

The data that would be obtained in this study were students' writing competency, students' response to the implementation of the strategy. The following were the instruments that used to collect the data. Instruments

1. Writing competency test

In order to know the students' writing competency, writing competency test was done to accomplish the purpose. The students were asked to write two kinds of paragraph namely: narrative and report. 
2. Questionnaire

Questionnaire was used to know the students' responses in writing competency and also to find whether or not the students have difficulties problem in writing competency. Further, questionnaire was used to find out students' response toward the use of the strategy.

\section{Observation Checklist}

This instrument was used in finding out whether or not the students followed the teaching learning process. This instrument contained the note told about the students' response and classroom situation along the teaching learning process.

Moreover, in the process of preliminary observation, there would be three kinds of instruments used, there were: writing test and interview. Further in the action process, the instrument used was an observation checklist in which it was exactly involved in the process of observation. Next, in the evaluation process, the instrument that would be used were a writing test and questionnaire. Then, in the reflection process, the researcher also used the observation checklist, the result of the test and questionnaire.

\section{DATA ANALYSIS}

Types of Data

In this study, there would be two kinds of data gained from the result of the preliminary observation and the result of test in cycle 1 and cycle 2 . There would be also be the result of informal interview and observation checklist. The quantitative data were gained from evaluation test. The result of the preliminary observation and the result of the observation checklist and questionnaire would be qualitative data.

On the other hand, the quantitative data would be analyzed by using descriptive analysis in which the result of the research would be described. After obtaining the result of the students' writing competency in the preliminary observation, the Idea-Details strategy would be implemented as the strategy in the learning process. After that the outcome of the students' writing competency would be obtained by doing an evaluation after each cycle. Next, to determine the improvement of students' learning, the results of the test after each cycle would be compared with results from preliminary observation. On the other hand, the qualitative data was analyzed in order to learn the students' writing competency was improved or not by using the Idea-Details strategy. The change would be analyzed based on the result of the observation checklist and questionnaire.

\section{TECHNIQUE FOR ANALYSING DATA}

The data that would be gathered to analyze as follows:

a. Quantitative data

The researcher accounted the evaluation test for each cycle by using these patterns.

1. Measuring the individual student's total score in each text.

$(($ Correct content $x 30)+($ Correct Organization $x$ 20) + (Correct Vocabulary $x$ 20) + (Correct grammar $x$ 25) $+($ Correct mechanics $\times 5))$

2. Measuring the percentage of students gaining lower than the standard score

$\% \mathrm{~N}<$ standard score= $\frac{\text { The number of students' achieving score }}{\text { The total member of students }} \times 100$

3. Measuring the percentage of students' gaining hogher or equal to the standard score

$\% \mathrm{~N} \quad \geq$ standard score=

$\frac{\text { The number of students' achieving score }}{\text { The total member of students }} \times 100$

4. Calculating the mean could be seen as follow:

$$
\text { Mean }=\frac{\text { The sum of the scores }}{\text { The number of the scores }}
$$

b. Qualitative data

\section{Observation checklist}

Observation checklist was used by the researcher to record the learning process in the class. Then, 
the researcher described the activity based on the observation checklist and compare from cycle 1 until cycle 2 .

2. Give questionnaires to the students.

For further information of the students' perception. The questionnaires were administrated to the students and then the researcher described the by showing the percentage of the students' response to each statement in the questionnaire.

\section{FINDING AND DISCUSSION}

Reflecting on the finding above, it could be stated that, after conducting the study by implementing the strategy, the purpose of the study has been achieved. Table 1 shows the number of the students that had improvement from each phase. The data of the students' writing competency had been obtained through the pre-test and evaluations.

Table 1 The Students' Writing Competency on Preliminary Observation, Cycle 1, and

\begin{tabular}{ccc}
\multicolumn{3}{c}{ Cycle 2 } \\
$\begin{array}{c}\text { R.indicator } \\
\text { Phases }\end{array}$ & $\sum \mathbf{n} \geq \mathbf{7 5}$ & $\%$ \\
\cline { 1 - 2 } $\begin{array}{c}\text { Pre- Obs. } \\
\text { Cycle 1 }\end{array}$ & 4 & $20 \%$ \\
\hline Cycle 2 & 17 & $35 \%$ \\
\hline
\end{tabular}

The data above indicates there was a progressive improvement in the percentage of students who obtained score higher or equal 75 from the preliminary observation, to cycle 1 and cycle 2 . More details of the score can be seen as follows.

Table 2. The Students' Mean Score in Each Phase

\begin{tabular}{rccc}
\hline & & Mean & \\
\cline { 2 - 4 } Student & Pre & C 1 & C 2 \\
\hline $\mathbf{1}$ & 65 & 68 & 78 \\
\hline $\mathbf{2}$ & 65.5 & 70 & 82.5 \\
\hline $\mathbf{3}$ & 62 & 64.5 & 75 \\
\hline $\mathbf{4}$ & 67 & 74 & 85.5 \\
\hline $\mathbf{5}$ & 75.5 & 76 & 82 \\
$\mathbf{6}$ & 59.5 & 68.5 & 78.5 \\
\hline $\mathbf{7}$ & 63.5 & 69 & 73 \\
\hline $\mathbf{8}$ & 75.5 & 74 & 83.5 \\
\hline $\mathbf{9}$ & 75.5 & 77.5 & 80.5 \\
\hline $\mathbf{1 0}$ & 70 & 71.5 & 76.5 \\
\hline $\mathbf{1 1}$ & 73 & 75.5 & 87.5 \\
\hline $\mathbf{1 2}$ & 72 & 78 & 80 \\
\hline $\mathbf{1 3}$ & 76.5 & 81.5 & 84.5 \\
\hline $\mathbf{1 4}$ & 72.5 & 73.5 & 77.5 \\
\hline $\mathbf{1 5}$ & 81.5 & 84 & 87 \\
\hline $\mathbf{1 6}$ & 71.5 & 72.5 & 75.5 \\
\hline $\mathbf{1 7}$ & 70 & 71.5 & 84.5 \\
\hline $\mathbf{1 8}$ & 75 & 80.5 & 83.5 \\
\hline $\mathbf{1 9}$ & 61 & 68 & 67.5 \\
\hline $\mathbf{2 0}$ & 65.5 & 65 & 68.5 \\
\hline
\end{tabular}


Note:

S: Students

$\begin{array}{ll}\text { Pre } & \text { : Pre-Observation } \\ \text { C1 } & \text { : Cycle } 1 \\ \text { C2 } & \text { : Cycle } 2\end{array}$

Although there were many of students that achieved the standard score or above the standard score, there were few of the students that had not achieved

the standard score. The problems came from some indicators that were not success to achieve by them. The details of problems that they encountered can be seen in table 3.

\begin{tabular}{|c|c|c|}
\hline Students & Indicators & Mean \\
\hline \multirow{5}{*}{7} & C & 23 \\
\hline & 0 & 16 \\
\hline & V & 14.5 \\
\hline & G & 16.5 \\
\hline & $M$ & 3 \\
\hline \multirow{5}{*}{19} & C & 20.5 \\
\hline & 0 & 13 \\
\hline & V & 13 \\
\hline & G & 17 \\
\hline & $\mathrm{M}$ & 4 \\
\hline \multirow{5}{*}{20} & C & 21.5 \\
\hline & $\mathrm{O}$ & 14 \\
\hline & $\mathrm{V}$ & 14 \\
\hline & G & 15 \\
\hline & $M$ & 4 \\
\hline
\end{tabular}

Based on the table above, the three students that did not reach the standard score, faced problem in some of indicators. Student 7 had problems in grammar and mechanics, whether the ideal score of grammar was 19 and mechanics was 4 . Student 19 had problems in content, organization, vocabulary, and grammar. The ideal score for content was 22, organization was 14 , and vocabulary was 14. Student 20 faced problems in content and grammar.

In order to shows more information about the improvements of the students' writing competency in narrative and report text, the improvement of the students is also illustrated like the following chart.

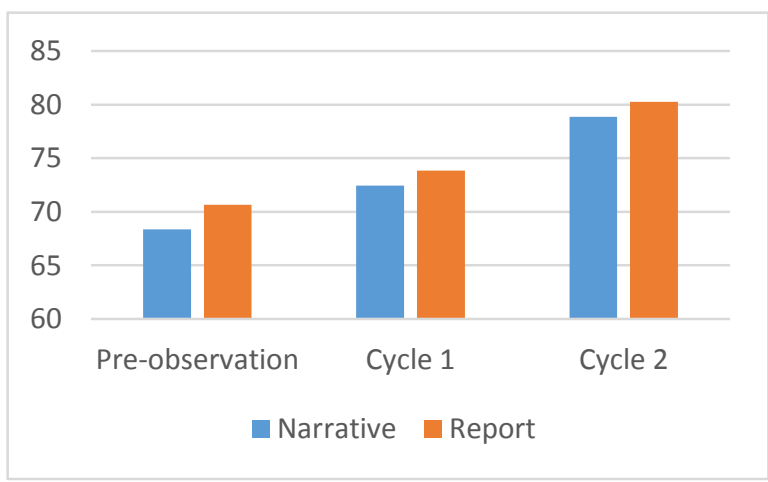

Figure 3. The Students' Writing Competency Improvement for Each Text 
The chart above shows the improvement of students' writing competency from preliminary observation until cycle 2 for each of text. Further, the students' improvement was also revealed by the percentage of students who achieved scores higher than or equal to minimum score in each text. The improvement can be seen by comparing the result of test in preliminary observation, cycle 1 , and cycle 2. The table below shows the percentage of students getting higher than or equal to the minimum score.

Table. 5 The Students' Writing Competency Based on Text

In Preliminary Observation, Cycle 1 and Cycle 2

\begin{tabular}{rcccc}
\hline \multirow{2}{*}{ Texts } & $\begin{array}{c}\text { Per. } \\
\text { Indicator }\end{array}$ & Pre & P1 & C2 \\
\cline { 2 - 5 } & $\sum \mathrm{n} \geq 75$ & 6 & 8 & 14 \\
\cline { 2 - 5 } Narrative & $\%$ & $30 \%$ & $40 \%$ & $70 \%$ \\
\cline { 2 - 5 } & Mean & 76.4 & 79.25 & 83.5 \\
\hline \multirow{2}{*}{ Report } & $\sum \mathrm{n} \geq 75$ & 6 & 7 & 17 \\
\cline { 2 - 5 } & $\%$ & $30 \%$ & $35 \%$ & $85 \%$ \\
\cline { 2 - 5 } & Mean & 69.5 & 79 & 81 \\
\hline
\end{tabular}

The data above shows that there was a progressive improvement in the percentage of students who obtained score higher than or equal to 75 from the preliminary observation, to cycle 1 and cycle 2 . In narrative text, the preliminary observation column shows there were 6 $(30 \%)$ students that achieved score equal or above the standard score. In cycle 1 there were $8(40 \%)$ students achieved score equal or above than the standard score. In cycle 2, there were 14 (70\%) students that achieved score equal or above than standard score. For the report text, there were $6(30 \%)$ students that achieved score equal or above the standard score. In the cycle 1, there were 7 $(35 \%)$ that achieved score equal or above the standard score. For the last was in cycle 2 , there were $17(85 \%)$ students that got score equal or above the standard score, whether the standard score was 75 . The improvement of the students' writing competency also can be seen in the table 6 . In this table shows the number of students that obtained ideal score or got higher score than the ideal score base on indicators. The details are illustrated as follow:

Table 6. The Students' Writing Competency based on Indicators In Preliminary Observation, Cycle 1, and Cycle 2

\begin{tabular}{|c|c|c|c|c|c|}
\hline Text & Indicators & $\begin{array}{l}\text { Performance } \\
\text { Indicators }\end{array}$ & $\begin{array}{l}\text { Preliminary } \\
\text { Observation }\end{array}$ & Cycle 1 & Cycle 2 \\
\hline \multirow{5}{*}{ 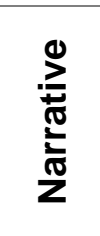 } & C & $\% n \geq 22$ & 3 & 11 & 19 \\
\hline & 0 & $\% n \geq 14$ & 14 & 14 & 16 \\
\hline & $\mathrm{V}$ & $\% n \geq 14$ & 4 & 14 & 16 \\
\hline & $\mathrm{G}$ & $\% n \geq 19$ & 4 & 12 & 14 \\
\hline & $\mathrm{M}$ & $\% n \geq 4$ & 9 & 13 & 17 \\
\hline \multirow{5}{*}{$\begin{array}{l} \pm \\
\frac{0}{0} \\
\underset{d}{0}\end{array}$} & C & $\% n \geq 22$ & 13 & 14 & 19 \\
\hline & $\mathrm{O}$ & $\% n \geq 14$ & 10 & 11 & 17 \\
\hline & $\mathrm{V}$ & $\% n \geq 14$ & 12 & 15 & 18 \\
\hline & $\mathrm{G}$ & $\% n \geq 19$ & 9 & 8 & 17 \\
\hline & $M$ & $\% n \geq 4$ & 11 & 15 & 10 \\
\hline
\end{tabular}


Note:

$\mathrm{C}=$ Content

$\mathrm{O}=$ Organization

$\mathrm{V}=$ Vocabulary

$\mathrm{G}=$ Grammar

$M=$ Mechanic

According to the data that had been explained above, it can be seen that the number of the students achieved score equal or higher than 75 increased. There were $85 \%$ of the total students who had successfully gained equal or higher than the standard score 75 in the last evaluation in cycle 2. However, there were still the $25 \%$ of the total students achieved score under the standard score. It can be said that the implementation of The Idea-Details Strategy was succeed to improve students' writing competency of XI IPA-2 in SMA N 1 Sukasada. In short, The Idea- Details Strategy gave positive contribution to the students' improvement in writing competency.

\section{CONCLUSION}

Based on the findings and discussion that had been presented in the previous chapter, it can be concluded that The IdeaDetails Strategy could improve the students' writing competency of class XI IPA-2 in SMA $N 1$ Sukasada. This was shown from the students' achievement in the preliminary observation test, evaluation 1 (cycle 1), and evaluation 2 (cycle 2). The students' writing competency was improved after implementing the steps of the strategy. The strategy was applied in two cycles. In the first cycle, the students were asked to make two columns, namely idea and details column. Then, the students were asked to think about their idea or what they wanted to write. After the students found their idea, the students were asked to write their idea in the idea column in order to make the topic sentence and then the students were asked to write the details or supporting sentences in the details column. After they finished writing the details, the students should compose a paragraph based on The Idea-Details column that they had made.

Their writing quality were also increased from the preliminary observation until cycle 2. This was because the implementation The Idea-Details Strategy that could make them easier to state their ideas and organizing their paragraph in a good order. The result of the two tests showed the percentage of students that achieved score higher or equal to 75 increased from the preliminary observation until cycle 2. The percentage of the students who achieved score higher or equal to 75 improved significantly from $20 \%$ in the preliminary observation to $35 \%$ in the cycle 1 to $85 \%$ in cycle 2 . Further, the students' mean also improved from 69.5 in the preliminary observation to 73.15 in the cycle 1 to 79.5 in the cycle 2 . Therefore, the study was stopped since the percentage of students who obtained a score higher than the standard score improved to more than $75 \%$ of the class.

Further, the quantitative data above was supported by the qualitative data which was obtained from the result of the questioners and classroom observation which was done by using observation checklist. The data showed that the students gave positive responses toward the implementation of the strategy and also the activity in the classroom. Therefore, it can be concluded that the writing competency of class XI IPA-2 of SMA N 1 Sukasada was improved through the implementation of The Idea-Details Strategy.

\section{SUGESSTION}

Based on the observation of the findings in this study, there are some points that is considered really important by the researcher since the implementation of The Idea-Details Strategy was successfully conducted.

\section{For the teacher}

The strategy is really recommended to apply for the teacher in class XI IPA-2 SMA $N 1$ Sukasada. The strategy can help students to produce a good writing. 
2. For the students

The students are highly recommended to apply this strategy in their writing activity. By applying this strategy, the students can easily organize their ideas since the steps in implementing the strategy is simple. Further, the students are also expected to learn the more information about text.

3. For subsequently researchers

It is recommended to the other researcher to apply the strategy in different types of class and also types of writing text. Hopefully, this strategy can give advantages or information for the others researcher that want to conduct a research in term of writing competency.

\section{REFERENCES}

Brown, H. Douglas. 2001. Teaching by Principle: An Interactive Approach to Language Pedagogy. New York: Adison Wesley Longman.

Gebhard, Jerry G. 1996. Teaching English as a Foreign or Second Language. A Teacher Self-Development and Methodological Guide. U.S.A: University of Michigan Press.

Green, Janis. 1990. Literacy at Home and School. Sydney: Primary English Teaching Association.

Heaton, J.B.1989. Writing English Language Test. New York: Longman Group UK

Kemmis, S and McTaggart, R. 1998. The Action Research Planner. Victoria: Dankin University.

Koshy, Valsa. 2005. Action Research for Improving Practice. London: Paul Chapman Publishing.

Langan, John. 2001. College Writing Skills with Reading, fifth edition. New York: McGraw-Hill Companies

McGraw-Hill.Palmer, C. Hafner, L. and Sharp, F. (1994).Developing Cultural Literacy throughthe Writing Process. Massachussets: Longwood.

Mills, Geoffrey, E. 2003. Action Research: A Guide for Teacher Researcher (2nd edition). New Jersey: Pearson Education Inc.

Natalia, M.K. 2011. Improving Students' Writing Competency Through The
Idea-Details Strategy in Class X-2 of SMA Negeri 3 Singaraja in The Academic Year 2010/2011.

Nunan, David. 2003. Practical English Language Teaching. Singapore:

Peha, Steve. 2003. The Writing Teachers' Strategy Guide. Available at http://www.ttms.org

Richards, Jack. C. and Renandya, W. A. 2002.Methodology in Language Teaching: An Anthology of Current Practice. Cambridge: Cambridge University Press.

Rubeinstein, C. 2013. What We Learn Through Writing. Retrieved from https://www.psychologytoday.com/bl og/now-is-everything/201301/7profound-quotes-what-we-learnthrough-writing

Tom, A. A. 2013. Students' Perception and Preferences of Written Feedback in Academic Writing. Mediterranean Journal of Social Sciences.

Tucker, K. 2015. Why Do Students Need to Learn How to Write? Retrieved from http://classroom.synonym.com/stude $\underline{\text { nts-need-learn-write-1325.html }}$ 